\title{
Tin(IV) Complexes of Schiff Base Derived from Amino Acid: Synthesis and Characteristic Spectral Studies
}

\author{
Robina Aman and Garima Matela \\ Department of Chemistry, Kumaun University, S. S. J. Campus, Uttarakhand Almora 263 601, India \\ Correspondence should be addressed to Robina Aman; amanrobina@yahoo.com
}

Received 30 April 2011; Accepted 10 November 2011

Academic Editor: Mohamed Farook

Copyright (c) 2013 R. Aman and G. Matela. This is an open access article distributed under the Creative Commons Attribution License, which permits unrestricted use, distribution, and reproduction in any medium, provided the original work is properly cited.

A new series of tin(IV) complexes of general formula [Sn(L-1)(Opr $\left.\left.{ }^{i}\right)_{2}\right](\mathbf{1}),\left[\mathrm{Sn}(\mathrm{HL}-1)_{2}\left(\mathrm{Opr}^{i}\right)_{2}\right](\mathbf{2})$, [Sn(L-2)(Opr $\left.\left.{ }^{i}\right)_{2}\right](\mathbf{3})$, [Sn(HL$\left.2)_{2}\left(\mathrm{Opr}^{i}\right)_{2}\right](4)$, (L is dianion of Schiff bases derived from the condensation of 2-hydroxy-1-naphthaldehyde with glycine (L-1) and ${ }_{L} \beta$-alanine (L-2)) was synthesized by reaction of tin(IV) tetraisopropoxide with the ligands, in appropriate stoichiometric ratios $(1: 1$ and $1: 2)$. This would result in the replacement of the isopropoxide group from the tin(IV) tetraisopropoxide and hydrogen(s) from ligand with the azeotropical removal of isopropanol. An attempt has been made to prove the structure of the resulting complexes on the basis of elemental analysis, IR, ${ }^{1} \mathrm{H}$ nuclear magnetic resonance. The binding site of the ligand was identified by IR spectroscopic measurement. In these complexes, the tin(IV) centre is bonded to oxygen atom of the hydroxyl or carboxylate group. The spectra data suggest that the carboxylate group is coordinated to tin(IV) centre in monodentate manner.

\section{Introduction}

The interest in tin chemistry has attracted considerable attention due to its remarkable industrial, medicinal, and agricultural applications [1-4], and the coordination behavior of tin metal with the biological active ligand has been studied since the last decade due to its wide applications in several areas such as antitumour [5], antiviral [6], bactericides, fungicides [7], marine antifouling paints, surface disinfectants, wood preservatives [8], and many more. Schiff base is an important class of ligand in coordination chemistry and has important and vast biological application in different fields [9]. The interaction of tin metal to the organic group via $\mathrm{O}-\mathrm{Sn}$ and $\mathrm{N}-\mathrm{Sn}$ bonds has aroused considerable interest in several research fields. Prompted by these facts, we have synthesized some tin(IV) complexes with Schiff bases and illustrated their geometrical structure by using spectral analysis.

\section{Experimental}

2.1. Materials and Methods. All the reagents, namely, tin (Merck), 2-hydroxynaphthaldehyde (Aldrich), were used as received. All the chemicals and solvents used were dried and purified by standard methods, and moisture was excluded from the glass apparatus using $\mathrm{CaCl}_{2}$ drying tubes.

The melting points were determined in open capillaries with electronic melting point apparatus. $\mathrm{C}, \mathrm{H}$, and $\mathrm{N}$ analyses of these compounds were carried out in a VarioEL, CHNS elemental analyzer. The tin content in the synthesized compounds was determined gravimetrically as $\mathrm{SnO}_{2}$. Infrared spectra of the solid compounds were recorded on a Perkin-Elmer 1600 series FT-IR spectrophotometer in the range $4000-400 \mathrm{~cm}^{-}$from $\mathrm{KBr}$ discs. ${ }^{1} \mathrm{H}$ NMR spectra were recorded on a Bruker DRX 300 (300 MHz FT NMR) spectrometer at the Central Drug Research Institute, Lucknow, India, using $\mathrm{CDCl}_{3}$ as a solvent and TMS as the internal standard.

2.2. Synthesis of Schiff Bases. Schiff bases were prepared by condensation of hot aqueous $(25 \mathrm{~mL})$ solution of glycine or alanine (.013 mole) and 2-hydroxy 1-naphthaldehyde (.013 mole), dissolved in ethanol $(50 \mathrm{~mL})$. The reaction mixture was refluxed for about $2 \mathrm{~h}$, and yellow brown polycrystalline precipitate was obtained after standing overnight. It was 
TABLE 1: Elemental analysis of complexes.

\begin{tabular}{|c|c|c|c|c|c|c|c|}
\hline \multirow{2}{*}{ S. no. } & \multirow{2}{*}{ Complexes } & \multirow{2}{*}{ Color (yield \%) } & \multirow{2}{*}{ M.P. $\left({ }^{\circ} \mathrm{C}\right)$} & \multicolumn{4}{|c|}{ Elemental analysis \% Obsd. (Calcd.) } \\
\hline & & & & $\mathrm{Sn}$ & $\mathrm{C}$ & $\mathrm{H}$ & $\mathrm{N}$ \\
\hline 1 & {$\left[\mathrm{Sn}(\mathrm{L}-1)\left(\mathrm{Opr}^{i}\right)_{2}\right]$} & Yellow (58) & $69-70$ & $25.68(25.60)$ & $49.32(49.17)$ & $4.99(4.96)$ & $2.98(3.02)$ \\
\hline 2 & {$\left[\mathrm{Sn}(\mathrm{HL}-1)_{2}\left(\mathrm{Opr}^{i}\right)_{2}\right]$} & Yellow (74) & $69-70$ & $17.18(17.13)$ & $55.49(55.44)$ & $4.98(4.91)$ & $3.99(4.04)$ \\
\hline \multirow[t]{2}{*}{3} & {$\left[\mathrm{Sn}(\mathrm{L}-2)\left(\mathrm{Opr}^{i}\right)_{2}\right]$} & Yellow (65) & $80-81$ & $24.9(24.85)$ & $50.31(50.24)$ & $5.26(5.23)$ & $2.89(2.93)$ \\
\hline & {$\left[\mathrm{Sn}(\mathrm{HL}-2)_{2}\left(\mathrm{Opr}^{i}\right)_{2}\right]$} & Yellow (76) & $80-81$ & $16.42(16.47)$ & $56.65(56.61)$ & $5.31(5.27)$ & $3.85(3.89)$ \\
\hline
\end{tabular}

TABLE 2: IR spectra of complexes (in $\mathrm{cm}^{-}$).

\begin{tabular}{lccccccc}
\hline S. no. $^{\text {a }}$ & Complexes & $v(\mathrm{OH} / \mathrm{NH})$ & $v_{\text {as }}(\mathrm{COO})$ & $v_{\mathrm{s}}(\mathrm{COO})$ & $\Delta \mathrm{v}(\mathrm{COO})$ & $v(\mathrm{Sn}-\mathrm{O})$ & $v(\mathrm{~N} \rightarrow \mathrm{Sn})$ \\
\hline 1 & {$\left[\mathrm{Sn}(\mathrm{L}-1)\left(\mathrm{Opr}^{i}\right)_{2}\right]$} & - & $1640 \mathrm{~s}$ & $1398 \mathrm{~m}$ & 242 & 538 & 415 \\
2 & {$\left[\mathrm{Sn}(\mathrm{HL}-1)_{2}\left(\mathrm{Opr}^{i}\right)_{2}\right]$} & 3400 & $1641 \mathrm{~s}$ & $1399 \mathrm{~m}$ & 242 & 532 & 418 \\
3 & {$\left[\mathrm{Sn}(\mathrm{L}-2)\left(\mathrm{Opr}^{i}\right)_{2}\right]$} & - & $1650 \mathrm{~s}$ & $1389 \mathrm{~m}$ & 261 & 540 & 430 \\
4 & {$\left[\mathrm{Sn}(\mathrm{HL}-2)_{2}\left(\mathrm{Opr}^{i}\right)_{2}\right]$} & 3414 & $1655 \mathrm{~s}$ & $1390 \mathrm{~m}$ & 265 & 535 & 432 \\
\hline
\end{tabular}

${ }^{a}$ Numbers as indicated in Table 2; s: strong; m: medium.<smiles>[R]C(N)C(=O)O</smiles>
$\left(\mathrm{R}=\mathrm{H}, \mathrm{CH}_{3}\right)$

SCHEME 1

$$
\begin{aligned}
& \mathrm{SnCl}_{4}+4 \mathrm{NaOPr}^{i} \longrightarrow \mathrm{Sn}\left(\mathrm{OPr}^{i}\right)_{4}+4 \mathrm{NaCl} \\
& \mathrm{Sn}\left(\mathrm{OPr}^{i}\right)_{4}+\mathrm{H}_{2} \mathrm{~L} \frac{\text { Benzene }}{1: 1 / 1: 2} \mathrm{Sn}\left(\mathrm{OPr}^{i}\right)_{2} \mathrm{~L} / \mathrm{Sn}\left(\mathrm{OPr}^{i}\right)_{2}(\mathrm{HL})_{2}+2\left(\mathrm{CH}_{3}\right)_{2} \mathrm{CHOH}
\end{aligned}
$$

SCHEMe 2

purified by repeated washing with aqueous-ethanol $(1: 2)$ and dried in vacuum over fused $\mathrm{CaCl}_{2}$ (Scheme 1) [10].

2.3. Synthesis of Complexes. The synthetic route used to synthesize complexes is outlined in Scheme 2. In the first step, $\mathrm{SnCl}_{4}$ was prepared by the action of chlorine gas on pure tin metal in a specially designed apparatus (bubbler). A pale yellow liquid of $\mathrm{SnCl}_{4}$ thus obtained was purified by distillation. The tin(IV) isopropoxide was synthesized by using literature method [11]. A solution of tin(IV) tetrachloride $(2.471 \mathrm{gm}, 0.0095$ mole) in benzene $(10 \mathrm{~mL})$ was treated with sodium isopropoxide ( $3.116 \mathrm{gm}, 0.038$ mole) to produce tin(IV) tetraisopropoxide and sodium chloride. The sodium chloride precipitate was removed by filtration, and the solvent was removed by distillation. The solution of tin(IV) tetraisopropoxide (3.528 gm, 0.0095 mole) and ligand
(2.372 gm, 0.01 mole) was refluxed in benzene for 8-10 h. These reactions proceed with the liberation of isopropanol, which is removed azeotropically with benzene.

\section{Result and Discussion}

All the newly synthesized complexes are colored solids and soluble in common organic solvents. The elemental analysis of these complexes is presented in Table 1.

3.1. Infrared Spectra. The characteristic infrared frequencies of the tin(IV) complexes are given in Table 2. It has been suggested, Schiff bases have a tautomeric structure (Figure 1), which means that pure Schiff bases exist in keto-amine and phenol-imine forms [12], but upon complex formation, they may exist only in the imine form. The complexes 
<smiles>O=C(O)C/N=C/c1c(O)ccc2ccccc12</smiles>

Phenol-imine form<smiles>O=C(O)CN/C=C1\C(=O)C=Cc2ccccc21</smiles>

Keto-amine form

FIGURE 1: Tautomeric form of Schiff base.<smiles>CC(C)O[Si]1(OC(C)C)OC(=O)CN(/C=C/c2cccc3ccccc23)O1</smiles>

(1)<smiles></smiles>

(3)<smiles>CC(C)O[N+](OC(=O)CN(C=Cc1c(O)ccc2ccccc12)[N+](=Cc1c(O)ccc2ccccc12)OC(=O)CO)(OC(C)C)OC(C)C</smiles>

(2)<smiles>CC(C)O[N+](OC(=O)C(C)/N=C/c1c(O)ccc2ccccc12)(OC(C)C)N(/C=C/c1c(O)ccc2ccccc12)C(C)C(=O)O</smiles>

(4)

Figure 2: Structure of tin (IV) complexes.

TABLE 3: NMR spectra of complexes (in $\delta$ ).

\begin{tabular}{lcccc}
\hline S. no. $^{\text {a }}$ & Complex & Azomethine proton & Methylene proton & Naphthylidene group proton \\
\hline 1 & {$\left[\mathrm{Sn}(\mathrm{L}-1)\left(\mathrm{Opr}^{i}\right)_{2}\right]$} & $9.16(\mathrm{~s}, 1 \mathrm{H})$ & $4.29(\mathrm{~s}, 2 \mathrm{H})$ & $6.91-7.92(\mathrm{~m}, 6 \mathrm{H})$ \\
2 & {$\left[\mathrm{Sn}(\mathrm{HL}-1)_{2}\left(\mathrm{Opr}^{i}\right)_{2}\right]$} & $9.12(\mathrm{~s}, 2 \mathrm{H})$ & $4.24(\mathrm{~s}, 4 \mathrm{H})$ & $6.89-7.88(\mathrm{~m}, 12 \mathrm{H})$ \\
3 & {$\left[\mathrm{Sn}(\mathrm{L}-2)\left(\mathrm{Opr}^{i}\right)_{2}\right]$} & $8.34(\mathrm{~s}, 1 \mathrm{H})$ & $3.58(\mathrm{~s}, 2 \mathrm{H})$ & $6.93-7.93(\mathrm{~m}, 6 \mathrm{H})$ \\
4 & {$\left[\mathrm{Sn}(\mathrm{HL}-2)_{2}\left(\mathrm{Opr}^{i}\right)_{2}\right]$} & $8.30(\mathrm{~s}, 2 \mathrm{H})$ & $3.56(\mathrm{~s}, 4 \mathrm{H})$ & $6.92-7.90(\mathrm{~m}, 12 \mathrm{H})$ \\
\hline
\end{tabular}

${ }^{a}$ Numbers as indicated in Table 3; s: singlet; m: multiplet.

1 and 3 do not show a strong band in the region of $3500-3300 \mathrm{~cm}^{-}$due to $v(\mathrm{OH} / \mathrm{NH})[13]$, indicating deprotonation of the phenolic and carboxylic oxygen of the Schiff bases on complex formation with the tin metal. In the complexes, two bands presumably due to asymmetric stretching frequencies $v_{\mathrm{as}}(\mathrm{COO})$ and symmetric stretching frequencies $v_{s}(\mathrm{COO})$ are observed at $1640-1655$ and $1389-1398 \mathrm{~cm}^{-}$, respectively. In the complexes, the differences $[\Delta \mathrm{v}(\mathrm{COO})]$ between $v_{\mathrm{as}}(\mathrm{COO})$ and $v_{\mathrm{s}}(\mathrm{COO})$ are $>200 \mathrm{~cm}^{-}$, indicating the unidentate coordination of the carboxylate group to the tin metal [14]. In the lower frequency region, the medium band observed at about $415-432 \mathrm{~cm}^{-}$in the spectra of the complexes has been assigned to the $v(\mathrm{~N} \rightarrow \mathrm{Sn})$ vibration [1517].

3.2. ${ }^{1} H$ NMR Spectra. Table 3 shows the chemical shifts $(\delta$ in ppm) of various protons in metal complexes. The absence 
of a signal due to the $-\mathrm{OH}$ proton at $\delta 12.00-13.00 \mathrm{ppm}$ suggests deprotonation of the phenolic/enolic/carboxylic oxygen atoms of the ligand on complexation [15]. The ${ }^{1} \mathrm{H}$ NMR Spectra of the complexes revealed a signal in the region $\delta 8.30-9.16 \mathrm{ppm}$ due to the azomethine $(-\mathrm{N}=\mathrm{CH}-)$ proton [18]. The multiplets between $\delta 6.89-7.93$ ppm are assigned to the naphthylidene group protons.

\section{Conclusion}

Based on stoichiometries and the physicochemical studies, penta- and octahedral coordination around tin(IV) has been proposed. The tentatively proposed structures of these complexes are shown in Figure 2.

\section{List of Abbreviations}

NaOPr ${ }^{i}$ : Sodium isopropoxide

$\mathrm{Sn}\left(\mathrm{OPr}^{i}\right)_{4}$ : $\mathrm{Tin}(\mathrm{IV})$ tetraisopropoxide

$v_{\text {as }}(\mathrm{COO})$ : Asymmetric stretching frequency

$v_{\mathrm{s}}(\mathrm{COO})$ : Symmetric stretching frequency

$\mathrm{CDCl}_{3}$ : Deuteriochloroform

IR: $\quad$ Infrared

NMR: $\quad$ Nuclear magnetic resonance.

\section{Acknowledgments}

The authors thank the U-COST, Dehradun, UK, for sanctioning the research project to Dr. R. Aman and awarding G. Matela as a JRF under the same project. The authors are also thankful to Professor Kamaluddin, Department of Chemistry, IIT Roorkee for spectral and elemental analysis.

\section{References}

[1] A. G. Davies and P. J. Smith, “Tin," in Comprehensive Organometallic Chemistry, G. Wilkinson, F. G. A. Stone, and E. W. Abel, Eds., vol. 2, p. 519, Pergamon Press, Oxford, UK, 1982.

[2] M. Kemmer, H. Dalil, M. Biesmans et al., "Dibutyltin perfluoroalkanecarboxylates: synthesis, NMR characterization and in vitro antitumour activity," Journal of Organometallic Chemistry, vol. 608, pp. 63-70, 2000.

[3] P. J. Smith, Chemistry of Tin, Blackie Academic and Professional, London, UK, 2nd edition, 1997.

[4] M. A. Esteruelas, F. J. Lahoz, M. Olivan, E. Onate, and L. A. Oro, "Oxidative addition of $\mathrm{HSnR} 3(\mathrm{R}=\mathrm{Ph}, \mathrm{nBu})$ to the squareplanar Iridium (I) compounds $\operatorname{Ir}(\mathrm{XR})(\mathrm{TFB})(\mathrm{PCy} 3)(\mathrm{XR}=\mathrm{OMe}$, OEt, OiPr, OPh, SnPr) and $\mathrm{Ir}(\mathrm{C} 2 \mathrm{Ph}) \mathrm{L} 2(\mathrm{PCy} 3)(\mathrm{L} 2=\mathrm{TFB}, 2$ CO)," Organometallics, vol. 14, pp. 3846-3896, 1995.

[5] M. Gielen, P. Lelieveld, D. Vos de, and R. Willem, "In vitro antitumour activity of organotin compounds," in Metal-Based Antitumour Drugs, M. Gielen, Ed., vol. 2, p. 29, Freund, Tel Aviv, Israel, 1992.

[6] P. B. Sreeja and M. R. P. Kurup, "Synthesis and spectral characterization of ternary complexes of oxovanadium(IV) containing some acid hydrazones and 2,2' -bipyridine," Spectrochim Acta A, vol. 61, no. 1-2, pp. 331-336, 2005.

[7] R. Singh and N. K. Kaushik, "Organotin(IV) complexes of thiohydrazides and thiodiamines: synthesis, spectral and thermal studies," Spectrochim Acta A, vol. 65, no. 3-4, pp. 950-954, 2006.
[8] P. Mazza, M. Orcesi, C. Pelizzi, G. Pelizzi, G. Predieri, and F. Zani, "Synthesis, structure, antimicrobial, and genotoxic activities of organotin compounds with 2,6-diacetylpyridine nicotinoyl- and isonicotinoylhydrazones," Journal of Inorganic Biochemistry, vol. 48, no. 4, pp. 251-270, 1992.

[9] M. T. H. Tarafder, N. Saravanan, K. A. Crouse, and A. M. B. Ali, "Coordination chemistry and biological activity of nickel(II) and copper(II) ion complexes with nitrogen-sulphur donor ligands derived from S-benzyldithiocarbazate (SBDTC)," Transition Metal Chemistry, vol. 26, no. 6, pp. 613-618, 2001.

[10] M. K. Singh, S. Bhaumik, and R. A. Lal, "Synthesis and characterization of tris[N-(2-oxo-1-naphthylidene )glycinato]manganese(III) and its reaction products with oxygen, nitrogen and/or sulphur donors," Journal of the Indian Chemical Society, vol. 84, no. 5, pp. 418-426, 2007.

[11] D. C. Bradley, D. P. Gaur, and R. C. Mehrotra, Metal Alkoxides, Academic Press, London, UK, 1978.

[12] I. Sakiyan, N. Gunduz, and T. Gunduz, "Synthesis and characterization of manganese(Iii) complexes of schiff bases derived from amino acids and 2-hydroxy-1-naphthaldehyde," Synthesis and Reactivity in Inorganic and Metal-Organic Chemistry, vol. 31, no. 7, pp. 1175-1187, 2001.

[13] M. Singh, "Cobalt(II), nickel(II) and copper(II) complexes of schiff bases derived from aminoacids and acetylacetone," Synthesis and Reactivity in Inorganic and Metal-Organic Chemistry, vol. 15, no. 2, pp. 235-246, 1985.

[14] M. Nath, H. Singh, G. Eng, and X. Song, "New diorganotin(IV) derivatives of dipeptides: synthesis and characteristic spectral studies," Spectrochimica Acta A, vol. 71, no. 2, pp. 529-536, 2008.

[15] M. Nath, C. L. Sharma, and N. Sharma, "Dibutyltin(IV) complexes of schiff bases derived from aminoacids," Synthesis and Reactivity in Inorganic and Metal-Organic Chemistry, vol. 21, no. 5, pp. 807-824, 1991.

[16] M. Nath, S. Goyal, and C. L. Sharma, "Studies of organotin(Iv) derivatives of thiosemicarbazones," Main Group Metal Chemistry, vol. 18, p. 51, 1995.

[17] M. Nath and S. Goyal, "Spectral studies and bactericidal, fungicidal, insecticidal and parasitological activities of organotin(IV) complexes of thio schiff bases having no donor atoms," MetalBased Drugs, vol. 2, no. 6, pp. 297-309, 1995.

[18] M. Nath, R. Yadav, M. Gielen, H. Dalil, D. de Vos, and G. Eng, "Synthesis, characteristic spectral studies and in vitro antimicrobial and antitumour activities of organotin(IV) complexes of schiff bases derived from amino-acids," Applied Organometallic Chemistry, vol. 11, no. 9, pp. 727-736, 1997. 

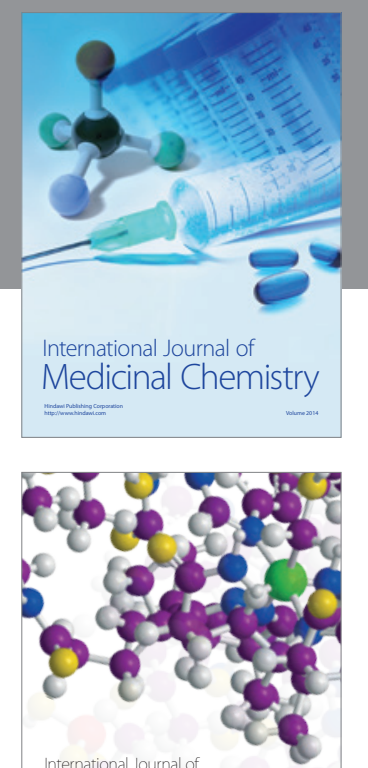

\section{Carbohydrate} Chemistry

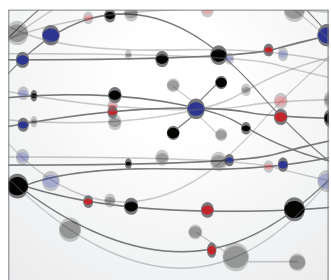

The Scientific World Journal
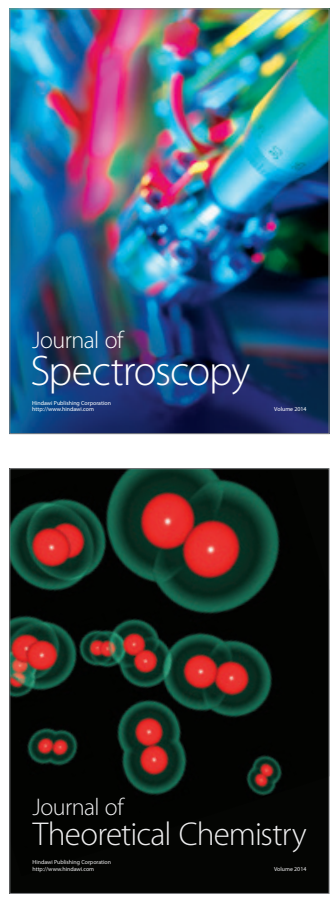
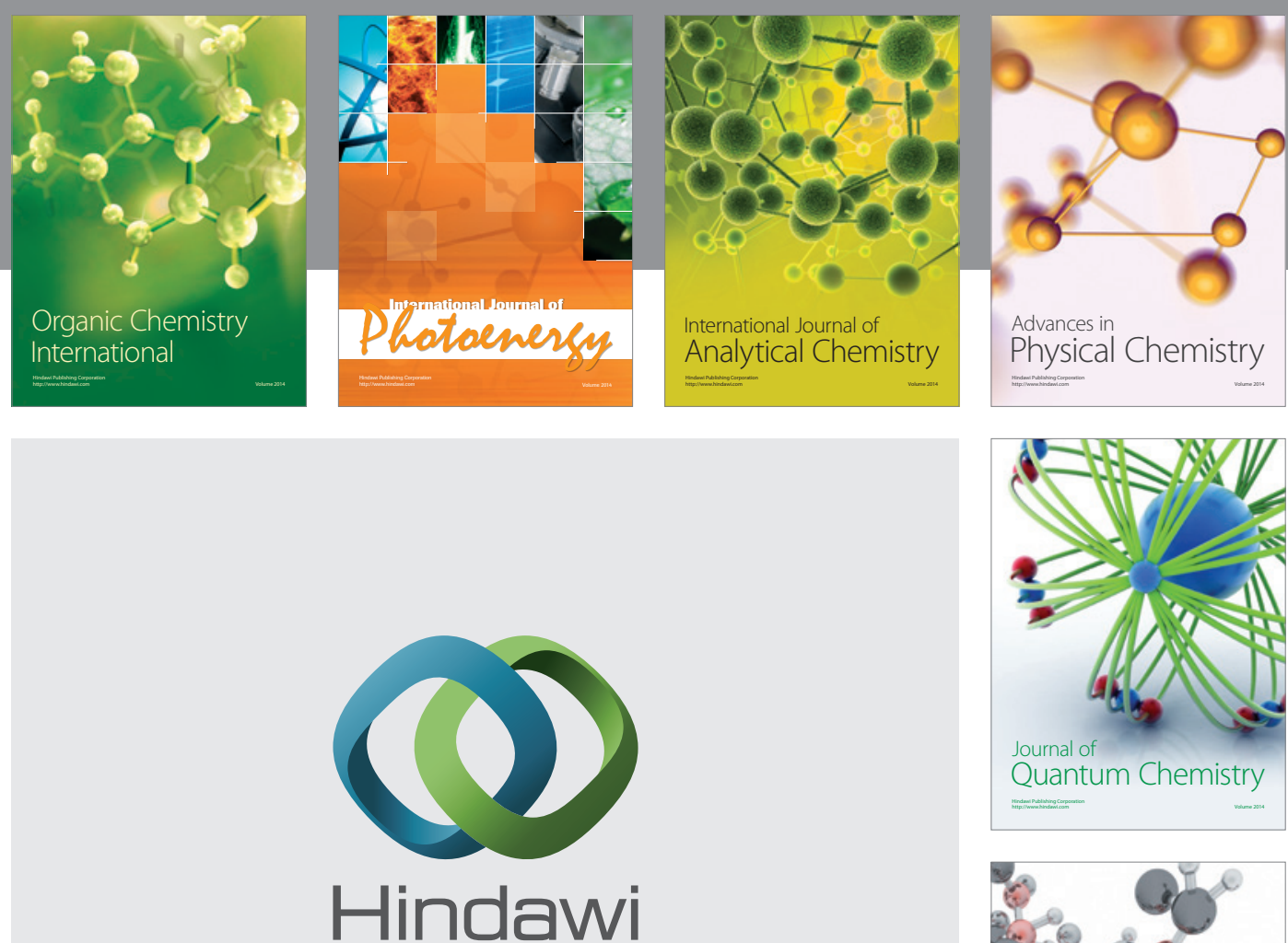

Submit your manuscripts at

http://www.hindawi.com

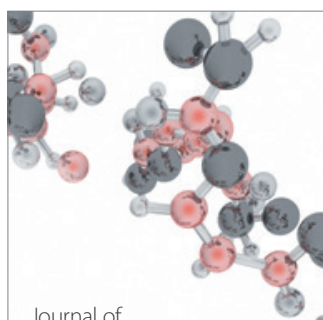

Analytical Methods

in Chemistry

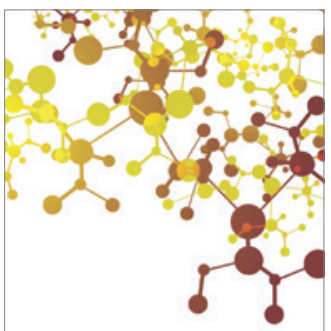

Journal of

Applied Chemistry

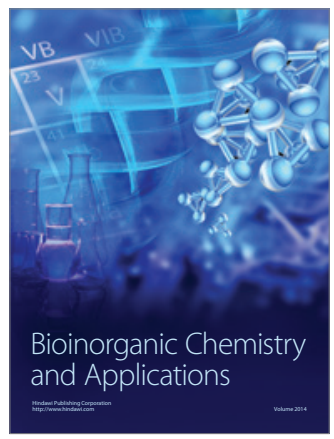

Inorganic Chemistry
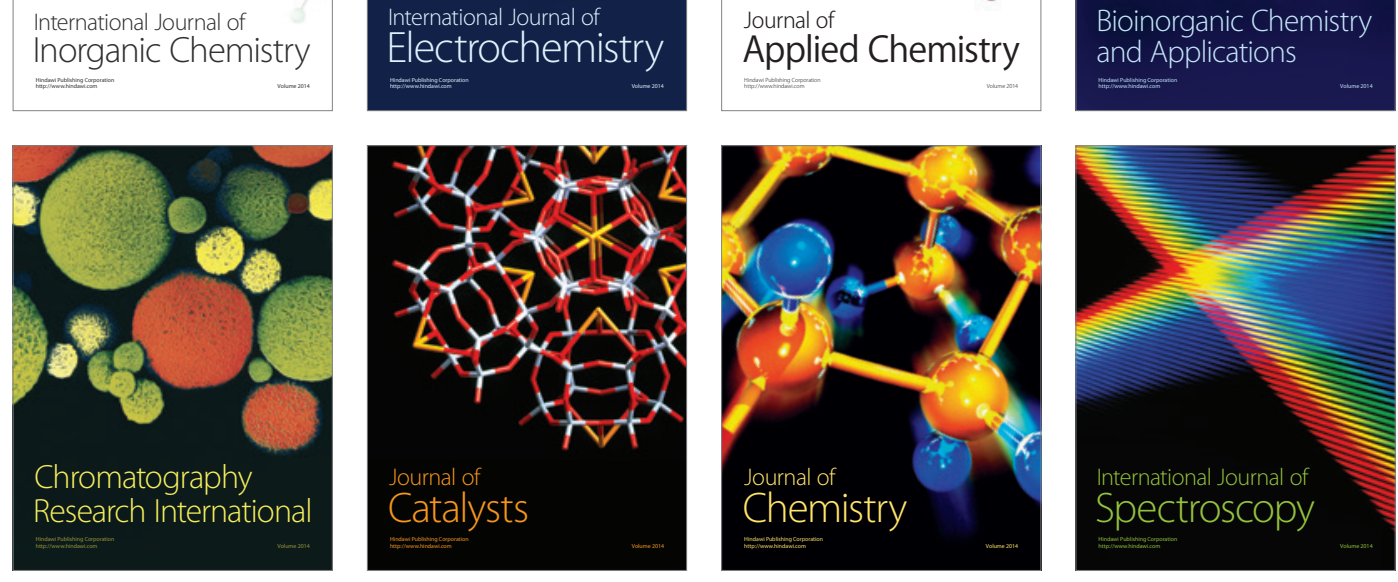